\section{The caddisfly Ylodes simulans (Trichoptera: Leptoceridae) in Scotland}

\author{
C.R. Macadam ${ }^{1}$, A. Dixon \& S. Crofts \\ ${ }^{1}$ Buglife - The Invertebrate Conservation Trust, \\ Balallan House, 24 Allan Park, Stirling FK8 2QG \\ E-mail: craig.macadam@buglife.org.uk
}

The caddisfly Ylodes simulans (Tjeder, 1929) is known from a single watercourse in Scotland: the River Forth in Stirlingshire, and has been found in only four other rivers in the U.K.: the River Teifi, River Dee, and Western Cleddau in Wales, and the De Lank River in Cornwall, England. It was first collected at Aberfoyle by William Evans in July 1906 (Morton, 1906). Wallace (1976) found it at three sites on the River Forth in June 1972:

Site 1 - immediately upstream of Aberfoyle (NN528010).

Site 2 - Kirkton upstream of Aberfoyle (NN515009).

Site 3 - Cardross near Arnprior (NS599973).

At all sites $Y$. simulans was found predominantly on beds of Myriophyllum sp. (Ian Wallace, pers. comm.).

The sites where $Y$. simulans had previously been recorded were visited on 24th May 2017 (Site 3 only) and 30th July 2018 (Site 1 and Site 2) when mature larvae should be present. A fourth site, on the Goodie Water downstream of the Lake of Menteith (NS596996), was also visited in 2018 as it was known to have extensive beds of Myriophyllum. Samples of the freshwater macro-invertebrates present were collected with a standard pond net $(0.25 \mathrm{~m}$ x $0.25 \mathrm{~m}$ frame; $1 \mathrm{~mm}$ mesh net). In addition, beds of Myriophyllum were searched for Leptoceridae larvae. Adult caddisflies were collected in July 2018 at Site 2 by sweeping vegetation with an entomological sweep net and light trapping using a bucket light trap with a $230 \mathrm{~mm} 6$ watt actinic tube, and a $600 \mathrm{~mm} 18$ watt actinic tube in front of a $1 \mathrm{~m} \times 1.5 \mathrm{~m}$ white sheet stretched between two poles.

On 30th July 2018 Site 1 and Site 2 upstream of Aberfoyle were visited. However, very little Myriophyllum was found and this took the form of only short $(c a .5 \mathrm{~cm})$ stems without any of the trailing stems characteristic of this species. Kick sampling, vegetation sweeping and light trapping failed to produce any specimens of $Y$. simulans.

At Site 3 at Cardross in May 2017 extensive beds of Myriophyllum were present. However, extensive searching did not find any specimens of $Y$. simulans. In July 2018 the river at Cardross was too high to sample, although it appeared that the extensive beds of
Myriophyllum found in May 2017 were no longer present.

At the fourth site on the Goodie Water there were extensive beds of Myriophyllum. Kick sampling, searching weed beds, and sweeping bankside vegetation failed to produce any specimens of $Y$. simulans.

The apparent loss of $Y$. simulans from the River Forth is concerning. The cause of this loss is unknown. However, the absence of large beds of Myriophyllum in the main river is likely to be a contributing factor. It is hoped that a remnant population is still present and further searches should be undertaken in the Forth catchment where Myriophyllum is found.

\section{REFERENCES}

Morton, K.J. (1906). Triaenodes reuteri, McLach., a species of Trichoptera new to Britain. Entomologist's Monthly Magazine 42, 270-271.

Wallace, I.D. (1976). The Taxonomy of Larvae of the British Species of the Family Leptoceridae (Trichoptera), with Notes on their General Biology. Ph.D. thesis, University of Newcastle upon Tyne. 